\title{
“Women's professional activity as an element of human capital management in the aspect of non-formal employment"
}

\begin{tabular}{|c|c|}
\hline AUTHORS & $\begin{array}{l}\text { Monika Pasternak-Malicka (D https://orcid.org/0000-0002-0011-7626 } \\
\text { R http://www.researcherid.com/rid/X-1696-2018 } \\
\text { Aldona Migała-Warchoł (D https://orcid.org/0000-0002-9756-3402 } \\
\text { R http://www.researcherid.com/rid/X-1686-2018 }\end{array}$ \\
\hline ARTICLE INFO & $\begin{array}{l}\text { Monika Pasternak-Malicka and Aldona Migała-Warchoł (2018). Women's } \\
\text { professional activity as an element of human capital management in the aspect of } \\
\text { non-formal employment. Problems and Perspectives in Management, 16(4), 375- } \\
\text { 383. doi:10.21511/ppm.16(4).2018.31 }\end{array}$ \\
\hline DOI & http://dx.doi.org/10.21511/ppm.16(4).2018.31 \\
\hline RELEASED ON & Thursday, 20 December 2018 \\
\hline RECEIVED ON & Saturday, 20 October 2018 \\
\hline ACCEPTED ON & Tuesday, 18 December 2018 \\
\hline ICENSE & $\begin{array}{l}(c) \text { EY } \\
\text { This work is licensed under a Creative Commons Attribution } 4.0 \text { International } \\
\text { License }\end{array}$ \\
\hline JOURNAL & "Problems and Perspectives in Management" \\
\hline SSN PRINT & $1727-7051$ \\
\hline SSN ONLINE & $1810-5467$ \\
\hline PUBLISHER & LLC "Consulting Publishing Company "Business Perspectives" \\
\hline FOUNDER & LLC "Consulting Publishing Company "Business Perspectives" \\
\hline
\end{tabular}

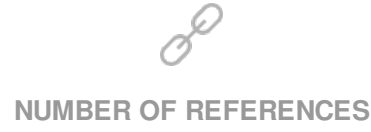

24

\section{NUMBER OF FIGURES}

6
ニニ:-

NUMBER OF TABLES

2

(C) The author(s) 2023. This publication is an open access article. 


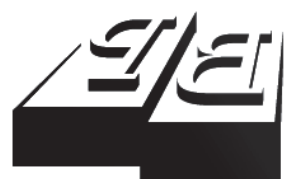

BUSINESS PERSPECTIVES

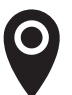

LLC "CPC "Business Perspectives" Hryhorii Skovoroda lane, 10, Sumy, 40022, Ukraine

www.businessperspectives.org

Received on: $20^{\text {th }}$ of October, 2018 Accepted on: $18^{\text {th }}$ of December, 2018

(C) Monika Pasternak-Malicka, Aldona Migała-Warchoł, 2018

Monika Pasternak-Malicka, Ph.D., Assistant Professor, Faculty of Management, Department of Finance, Banking and Accounting, Rzeszów University of Technology, Poland.

Aldona Migała-Warchoł, Ph.D. Assistant Professor, Faculty of Management, Department of Quantitative Methods, Rzeszów University of Technology, Poland.

\section{(ㄷ) (1)}

This is an Open Access article, distributed under the terms of the Creative Commons Attribution 4.0 International license, which permits unrestricted re-use, distribution, and reproduction in any medium, provided the original work is properly cited.

\begin{abstract}
The aim of the article is an attempt to assess the impact of women's occupational activity on the tendency to take up informal employment as an element of human capital management. The paper attempts to assess the relationship between the unemployment rate and the employment rate and the share of informal work in GDP. Methodology: The implementation of the objective required the use of statistical methods, in particular, linear regression methods. Results: The publication describes the nature of informal employment, the level of professional activity of women in the selected European Union countries in 2017. Based on statistical data, an attempt was made to assess the impact of professional activity among women on non-formal work based on the linear regression method.
\end{abstract}

\section{Keywords \\ human capital management, labor market, undeclared work, unemployment}

\section{JEL Classification E260, K420, J010, J160, J240}

\section{INTRODUCTION}

Gender is one of the key features used in the analysis of the labor market. Women often work in professions other than men, they also receive other wages and working hours. This diversity is also dictated by other factors, such as the level of education, involvement in family life and even life expectancies. At the same time, the tendency to be active in the gray economy of the labor market is a derivative of the possibility of getting employment in the official sector.

The aim of the article is an attempt to assess the impact of professional activity of women on the inclination to take up informal employment. The paper attempts to assess the relationship between the unemployment rate and the employment rate and the share of informal work in GDP. The implementation of the objective required the use of statistical methods, in particular, linear regression methods. The article adopted a research hypothesis assuming that the phenomenon of unemployment affects the undeclared employment of women. Due to editorial limitations, the influence of other factors that may have an impact on activity in the shadow economy of the labor market was overlooked, and the focus was only on the relationship between the phenomenon of unemployment and undeclared work.

The first part of the publication describes the essence of informal employment in the European Union according to estimates by Schneider (2007) and Eurostat (2018), as well as the situation of women on the 
labor market in 2017 in the selected EU countries. Next, the employment rates for men and women for 2010 and 2017 were compared. On the basis of statistical data, an attempt was made to assess the impact of professional activity on the scope of informal work based on the linear regression method.

\section{HUMAN CAPITAL MANAGEMENT AND INFORMAL WORK}

In recent years, human capital management has gained a very high rank not only in the scientific forum, but also in business practice. It becomes necessary to develop a new set of stimuli and different shaping of incentive situations in individual companies. Also a strong influence of the state on the personal sphere of the organization requires adaptation. Also changes in the structure of groups of professionally active people in individual countries and regions are the reason for attempts to adapt activities in the personnel sector of the organization to more and more frequent phenomena such as increased participation of women in employment or the specificity of employment due to gender.

In the literature, there can be met many, not always precisely formulated, expressions of human capital. The ambiguity of this concept is primarily the result of the level of consideration - one can consider this phenomenon at the level of the national economy, at the level of the organization, or individual. The theory of human capital shows workers as individuals with specific skills that can be "rented" to employers for a fee (Ehrenberg \& Smith, 1997). In a broader sense, human resources management is a set of organization's activities aimed at acquiring, developing and maintaining an effective workforce (Griffin, 2013).

Managing human capital is currently one of the most important areas of management in the 21st century, when it was once classified as a secondary task (Writh \& McMahan, 1992). However, the fact that human resources are different compared to other resources must be taken into account. Two characteristics are especially different: the employer has the right to use his employees' skills and experience in a certain way, which is included in the employment contract and the supervisor does not become the owner of the employee, as in the case of material resources.
Human resources are of great importance for the effective functioning of the organization (Terpstra \& Rozell, 1993). The importance of human capital management is due to many reasons. One of the main reasons is the fact that it is people who decide how to use all the resources of an enterprise. Whether the business entity succeeds depends primarily on the skills and attitudes of the people who work in it (Davenport, 1999). Without them, even the best and most competitive material, monetary or information resources can be wasted and contribute to the failure of the organization (Penrose, 1997).

Currently, managers are aware of the fact that effective human resource management has a huge impact on the financial results of the entity. Improper management of human resources may lead to accumulation of employees recruitment with periodical redundancies, which is very costly from the point of view of not only payment of unemployment benefits, expenses for training, but also moral attitudes and attitude to work (Lado \& Wilson, 1994). Employment outside the register will not be conducive to acquiring, retaining and motivating good employees, and not concluding employment contracts may expose the company to expensive and embarrassing court complaints.

Employment changes are also affected by social changes. First, more and more organizations recruit employees periodically. This tendency allows them to increase employment if necessary without the risk that they will have to liquidate these jobs in the future. The same applies to informal employment. Thanks to this approach, labor costs are also reduced, because the pension and health insurance contributions are not deducted from these employees, nor are income taxes payable from their remuneration. At the same time, these employees are generally less loyal to the organization and sometimes lack specialized skills that would allow them to achieve higher results (Fierman, 1994). Another social change is the model of the modern family, in which both adults work in earnings most often. In this case, the form 
of illegal work is sometimes more flexible than traditional employment, which makes it more advantageous for both parties: employee and employer.

At the same time, the professional activity of women in many regions of the EU is still not satisfactory. Employers often think that due to longterm lack of contact with the practice in the industry, qualifications have become outdated, and the break has resulted in falling out of the work rhythm. Women - mothers are considered by employers to be less available and less devoted to work due to the burden of family duties. It also involves absenteeism resulting from children's diseases. In such a situation, the employer often prefers to hire a woman without a contract, without paying contributions during the absence period, and the conditions of such a contract are more convenient for him due to the flexibility of employment. In the case of a woman with offspring, the possibility of receiving family benefits (among others from the Family $500+$ program) is also a motivating factor for undertaking informal employment.

\section{THE CONCEPT AND SCALE OF ILLEGAL WORK}

One of the inseparable elements of the labor market is the existence of illegal and undeclared work along with official employment. The difference between illegal and undeclared work is very subtle. It is sometimes assumed that undeclared work refers to the violation of administrative rules, while illegal work is identified with criminal behavior. Most often, however, due to the blurred borders, both concepts are treated as identical. Despite the universality of the phenomenon of illegal work on a global scale, it has not developed a uniform definition. These areas of activity are interrelated and change under the influence of social and economic factors (Hussmanns, 2004). It was worth stressing that the size of informal work depends not only on financial factors, the situation on the labor market, or legal regulations, but also on the mentality of a given society (Jędrzejowska-Schiffauer \& Schiffauer, 2017).

In the literature, one can find a distinction between illegal employment and illegal work in the shadow economy (Cassel \& Caspers, 1984). The first case concerns the performance of work in terms of employment, but without the conclusion of a formal contract, and in the second case, it is about actions aimed at achieving self-sufficiency in meeting own needs (e.g., neighborhood assistance) (Mróz, 2002). The European Commission considered for undeclared work the payable performance of activities, by their very nature consistent with the legal order, but not reported to public authorities (European Commission, 1998). The European Commission defines the shadow economy as being "those economic activities and the income derived from them that circumvent or avoid government regulations or taxation".

In a broader sense, the term of the shadow economy consists of all undeclared or insufficiently declared production. In a narrow sense, this term does not include illegal economic activities or the informal domestic economy, but includes all production resulting from the market of goods and legal services which is deliberately concealed from the public authorities (Schneider et al., 2010, p. 5).

Schneider specializes in research on the gray economy area, which calculates the share of the informal economy in GDP based on the MIMIC method (Multiple Indicators Multiple Causes) (Torgler \& Schneider, 2007; Medina \& Schneider, 2018; Simionescu et al., 2016).

Figure 1 presents estimates in the selected EU countries in 2016. The smallest share was recorded in Austria, the Netherlands and the United Kingdom, where the shadow economy approached $8 \%$ of GDP, while the largest was recorded in Bulgaria, where the rate was about $1 / 3$ of GDP.

Illegal work is essentially a product of two main factors: the incentives of employers to avoid the costs of employing legal labor and law which restricts opportunity for legal labor migration. In some sectors of employment - such as agriculture, construction, hotel and catering, tourism, or cleaning - the restriction of legal work migration possibilities since the 1970s and a lack of supply of workers willing to do low-status, low-paid or seasonal work gives them opportunity to hire illegal immigrant (Boswell \& Straubhaar, 2004; Mikalauskiene et al., 2017). 
Source: Author's calculations based on Medina and Schneider (2018).

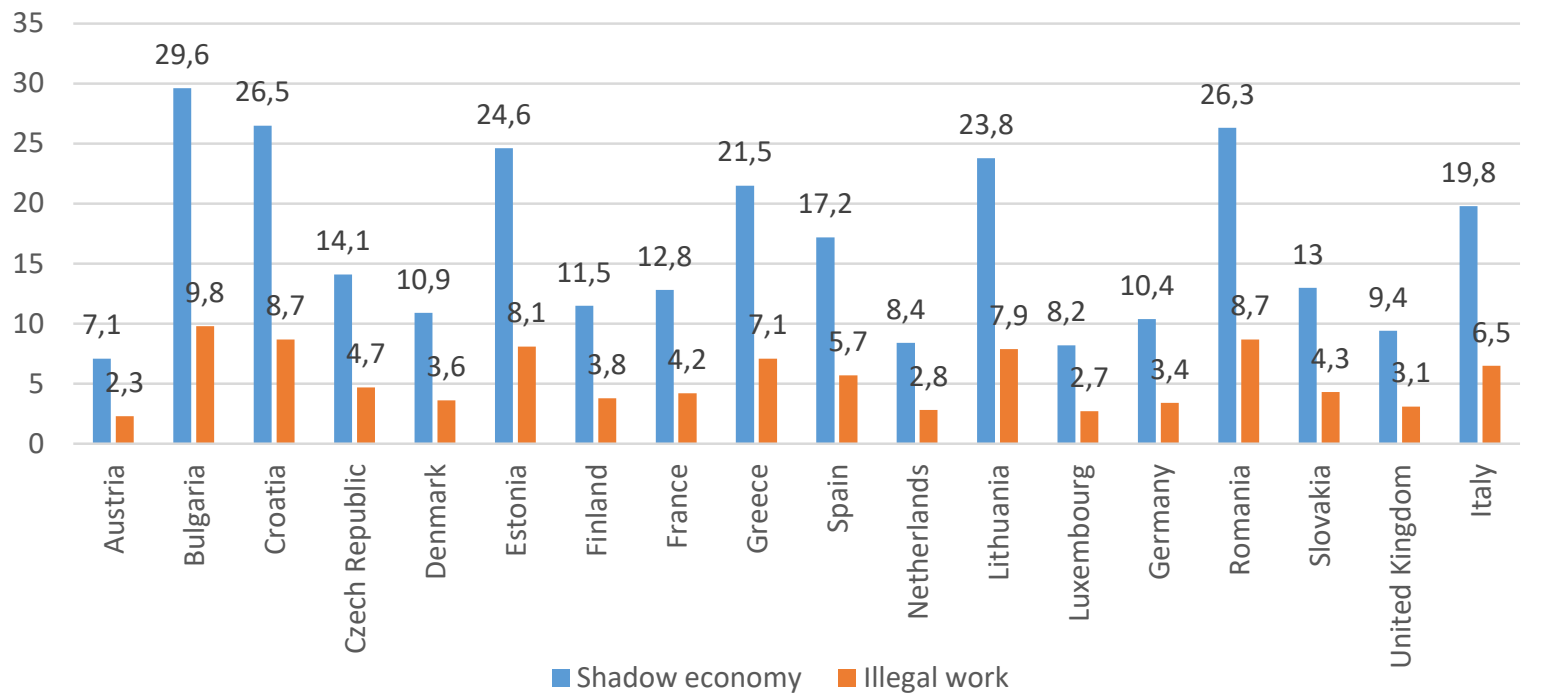

Figure 1. Informal economy and the level of undeclared work according to Schneider in the selected EU countries in 2017 (in \%)

Non-formal work is found in industries where manual labor plays the key role, for example, agriculture, construction, retail, catering or domestic services. It is often found in the production sector where competitiveness depends mainly on costs, or even in innovative IT sectors. Non-declared employment is rarely the result of a real choice. The alternative is often not to work or to do a work that does not pay enough to live in dignity.

The illegal employment could contain more than two thirds of the active population before 2020, according to Jütting and Laiglesia (2009) who also forecast that - less qualified or more sensitive - women, young people or the elderly will be particularly concerned. European companies in difficult situation will be increasingly forced to hire non-declared employees, or to do business with Polish companies, for example, instead of others.

In developing countries, women are employed in a disproportionately large number in the most vulnerable jobs in non-formal work, for example, being hired as family workers. Furthermore, although generally both men and women have lower rewards on average when working illegally, earnings differences between formal and informal employees are larger for women than for men (Kucera \& Xenogiani, 2009).

\section{RESEARCH RESULTS}

Figures 2-3 show linear regression models, in which Shadow Economy is the dependent variable, and the independent variable on the first chart is employment rate, and on the second one is unemployment rate.

Figures 4-5 show linear regression models, in which Illegal Work is the dependent variable, and the independent variable on the first chart is employment rate, and on the second one is unemployment rate.

Figures 2-5 illustrate scatterplots prepared based on Eurostat data for the year 2017. Analyzing the results, it should be stated that between the Shadow Economy and employment rate variables an average negative dependence was obtained, which is indicated by the value of Pearson's linear correlation coefficient $(r=-0.41)$. In the case of the study of the relationship between Shadow Economy and unemployment rate variables, Pearson's linear correlation coefficient was obtained at 0.25 , which means low positive dependence, which can be interpreted as follows: the situation on the labor market, the lack of flexible employment options can significantly influence the tendency of women to take up informal employment. 


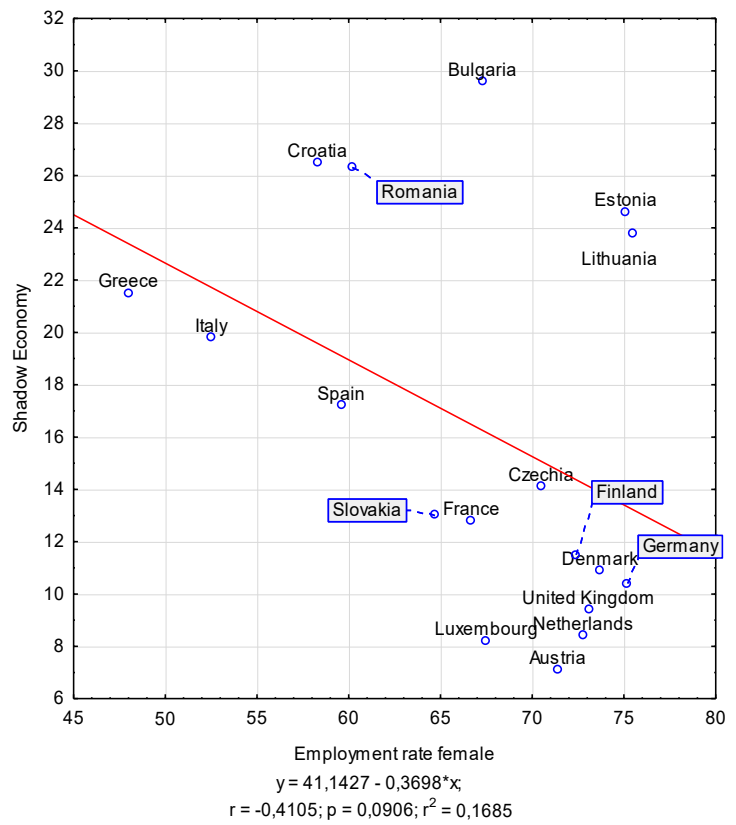

Figure 2. Regression model for shadow economy in terms of employment rate for women in the selected European Union countries

Source: Author's calculations.

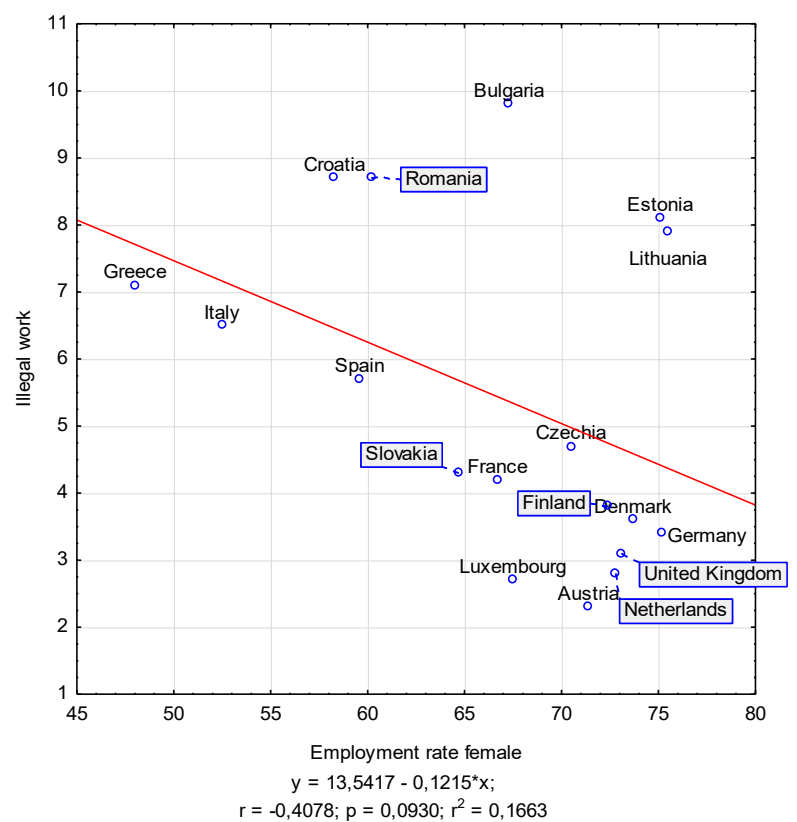

Figure 4. Regression model for illegal work in terms of employment rate for women in the selected European Union countries

Similar analysis was prepared for the Illegal Work variable and it was obtained that between the Illegal Work and employment rate variables an av-

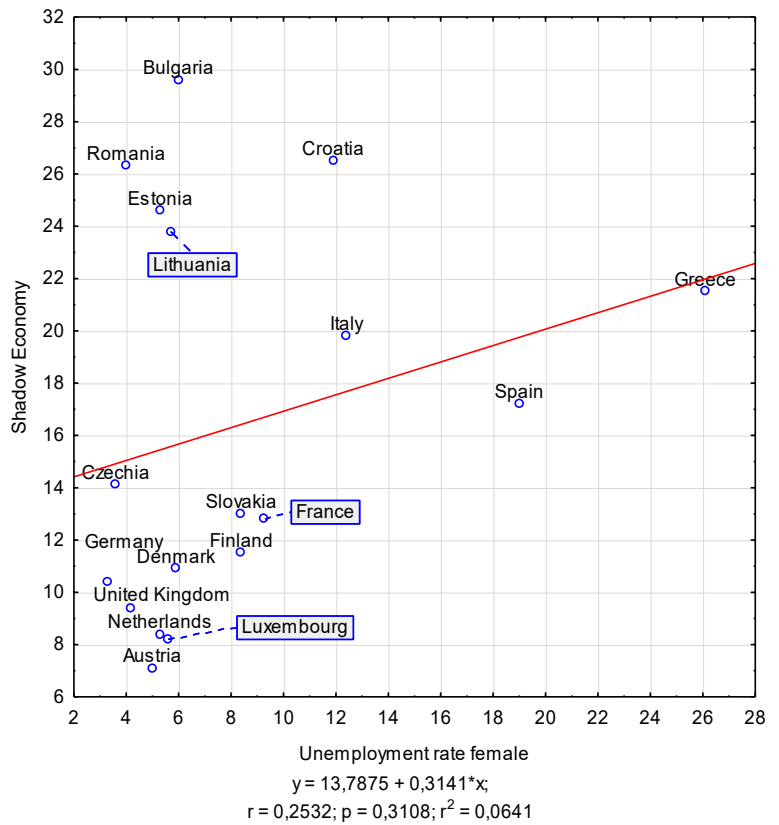

Figure 3. Regression model for shadow economy in terms of unemployment rate for women in the selected European Union countries

Source: Author's calculations.

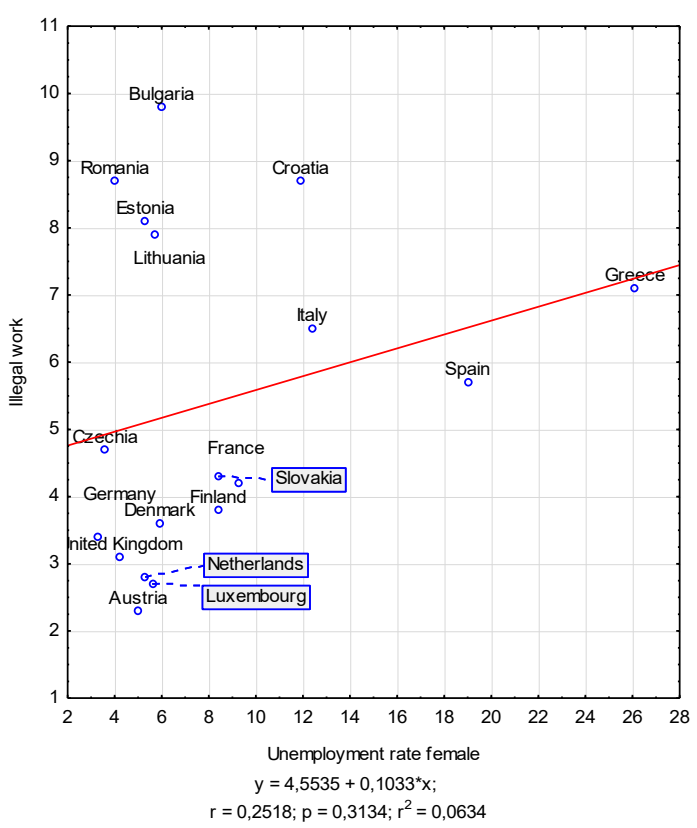

Figure 5. Regression model for illegal work in terms of unemployment rate for women in the selected European Union countries

erage negative dependence was achieved, which is indicated by the value of Pearson's linear correlation coefficient $(r=-0.41)$. In the case of the study 
of the relationship between Illegal Work and unemployment rate variables, Pearson's linear correlation coefficient was obtained at 0.25 .

The obtained regression models allow for the interpretation of parameters as follows: if the employment rate increases by 1 , Shadow Economy decreases by 0.37 , if the unemployment rate increases by 1, then Shadow Economy will increase by 0.31 , if the employment rate increases by 1 , then Illegal Work will decrease by 0.12 , if the unemployment rate increases by 1 , Illegal Work will increase by 0.1 .

2010 was chosen for a comparative analysis, due to the fact that during this period the impact of subprime crisis on the economic situation of EU countries, including the labor market, could be noticed.

On the basis of the last two columns of Table 1, Chart 6 was prepared, which presents differences in the employment rate in the European Union for women and men for the years 2010 and 2017. The calculated differences for 2017 show that Lithuania, Finland and Sweden have reached the smallest values, while the biggest differences were obtained by Greece, Italy and Malta.

For the majority of countries, values for 2017 are lower than for 2010. Only for countries such as Lithuania, Finland, Latvia, Denmark, Estonia, Bulgaria, Ireland, Poland, Hungary

Table 1. Employment rate gender gap in the European Union countries for the years 2010 and 2017

Source: Author's calculations based on Eurostat data.

\begin{tabular}{|c|c|c|c|c|c|c|}
\hline \multirow{2}{*}{ Countries } & \multicolumn{2}{|c|}{2010} & \multicolumn{2}{|c|}{2017} & \multicolumn{2}{|c|}{ Gender gap } \\
\hline & Male & Female & Male & Female & 2010 & 2017 \\
\hline EU 28 & 75.1 & 62.1 & 78 & 66.5 & 13 & 11.5 \\
\hline Euro area & 75 & 61.8 & 76.6 & 65.4 & 13.2 & 11.2 \\
\hline Belgium & 73.5 & 61.6 & 73.4 & 63.6 & 11.9 & 9.8 \\
\hline Bulgaria & 68.6 & 60.8 & 75.3 & 67.3 & 7.8 & 8 \\
\hline Czechia & 79.6 & 60.9 & 86.3 & 70.5 & 18.7 & 15.8 \\
\hline Denmark & 78.6 & 73 & 80.2 & 73.7 & 5.6 & 6.5 \\
\hline Germany & 80.4 & 69.7 & 83.1 & 75.2 & 10.7 & 7.9 \\
\hline Estonia & 67.8 & 65.9 & 82.4 & 75.1 & 1.9 & 7.3 \\
\hline Ireland & 69.9 & 61.1 & 79.1 & 67 & 8.8 & 12.1 \\
\hline Greece & 76 & 51.8 & 67.7 & 48 & 24.2 & 19.7 \\
\hline Spain & 69.2 & 56.3 & 71.5 & 59.6 & 12.9 & 11.9 \\
\hline France & 74 & 64.9 & 75 & 67.2 & 9.1 & 7.8 \\
\hline Croatia & 67.9 & 56.4 & 68.9 & 58.3 & 11.5 & 10.6 \\
\hline Italy & 72.7 & 49.5 & 72.3 & 52.5 & 23.2 & 19.8 \\
\hline Cyprus & 81.7 & 68.8 & 75.7 & 66.2 & 12.9 & 9.5 \\
\hline Latvia & 64 & 64.5 & 77 & 72.7 & -0.5 & 4.3 \\
\hline Lithuania & 63.5 & 65 & 76.5 & 75.5 & -1.5 & 1 \\
\hline Luxembourg & 79.2 & 62 & 75.4 & 67.5 & 17.2 & 7.9 \\
\hline Hungary & 65.5 & 54.6 & 81 & 65.7 & 10.9 & 15.3 \\
\hline Malta & 78.2 & 41.6 & 84.7 & 60.6 & 36.6 & 24.1 \\
\hline Netherlands & 82.8 & 70.8 & 83.3 & 72.8 & 12 & 10.5 \\
\hline Austria & 79 & 68.8 & 79.4 & 71.4 & 10.2 & 8 \\
\hline Poland & 71.3 & 57.3 & 78.2 & 63.6 & 14 & 14.6 \\
\hline Portugal & 75.4 & 65.6 & 77.3 & 69.8 & 9.8 & 7.5 \\
\hline Romania & 73.1 & 56.5 & 77.3 & 60.2 & 16.6 & 17.1 \\
\hline Slovenia & 74 & 66.5 & 76.9 & 69.7 & 7.5 & 7.2 \\
\hline Slovakia & 71.9 & 57.4 & 77.5 & 64.7 & 14.5 & 12.8 \\
\hline Finland & 74.5 & 71.5 & 75.9 & 72.4 & 3 & 3.5 \\
\hline Sweden & 81.1 & 75 & 83.8 & 79.8 & 6.1 & 4 \\
\hline United Kingdom & 79.3 & 67.9 & 83.4 & 73.1 & 11.4 & 10.3 \\
\hline
\end{tabular}




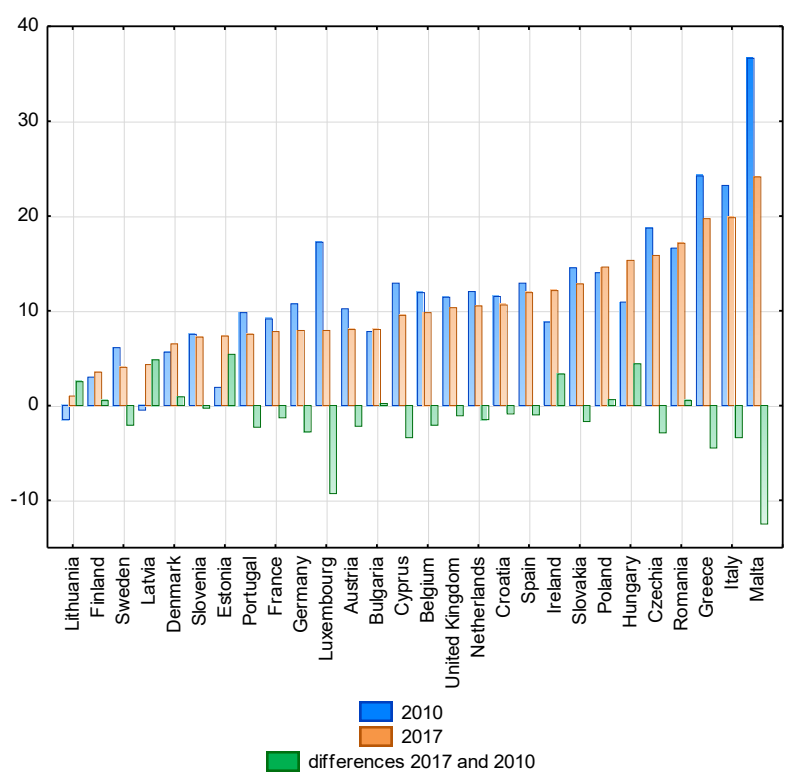

Source: Author's calculations.

Figure 6. Employment rate gender gap in the European Union countries for the years 2010 and 2017

Table 2. Wilcoxon matched pairs test for the years 2010 and 2017

Source: Author's calculations.

\begin{tabular}{|c|c|c|c|c|}
\hline \multirow{2}{*}{ A pair of variables } & \multicolumn{4}{|c|}{$\begin{array}{l}\text { Wilcoxon matched pairs test (employment rates for } 2010 \text { and 2017) } \\
\text { The results are statistically significant with } p<.05000\end{array}$} \\
\hline & $\mathbf{N}$ & $\mathbf{T}$ & $\mathbf{Z}$ & $\mathbf{p}$ \\
\hline Male 2010 and male 2017 & 30 & 64.5 & 3.46 & 0.000549 \\
\hline Female 2010 and female 2017 & 30 & 21 & 4.35 & 0.000014 \\
\hline
\end{tabular}

and Romania the values of the differences obtained are higher for 2017.

Table 2 presents the matched pairs test of Wilcoxon for the years 2010 and 2017. There was a compari- son made for the employment rate for men in 2010 and 2017 and for the employment rate for women in 2010 and 2017. The results indicate the significant changes in the differences for both men and women between the years 2010 and 2017.

\section{CONCLUSION}

Hundreds of millions of women work around the world, but the types of job they do are often informal, or lower quality, worse paid than those performed by men. They are often casualties of socio-economic factors. Undeclared work is a phenomenon of many dimensions, but nonetheless gives the opportunity to obtain income so-called marginal work force. In addition, it makes the form of employment more flexible making it more convenient for mothers or people caring for older family members. The share of people working in the black economy depends on the economic situation, or more strictly from the situation on the labor market. In the period when the unemployment rate is high, the position of employees towards potential employers is weaker. Then, jobseekers are more likely to agree to employment without a contract, especially if it is associated with higher wages (as a consequence of non-payment of taxes and social security contributions).

This theoretical observation is reflected in empirical data and statistical calculations. According to estimates by Schneider (2007) and Eurostat (2018) data, the scope of the informal economy, including undeclared work in the European Union is systematically dropping. Informal employment concerns from 2.3 to $9.8 \%$ of employed persons, although it is reduced in absolute numbers. One of the important rea- 
sons for illegal work is the lack of places in the official sector, as well as social benefits. It is assumed that higher unemployment is usually accompanied by a larger share of illegal work. The analyzes carried out seem to confirm this dependence. There was also a positive correlation between the unemployment rate and the level of illegal employment according to estimates by Schneider (2007). On the other hand, the negative relationship is between the employment rate and the scale of illegal work, which may indicate that a good situation at the labor market encourages employees to legalize the employment relationship.

Unemployment, professional activity and employment rates are much more beneficial to men than women. The legal regulations and preferences of employers mean that even women who have already found a job, but have decided to motherhood, or look after older, not fully functional parents, cannot always count on stable employment. Sometimes the only alternative to this group is illegal work, without social security, but bringing real, short-term income and making employment more flexible.

For the majority of EU countries, differences in the employment rate by gender are lower for 2017 in relation to 2010. The tests were completed with the Wilcoxon matched pairs test, which allowed to state that the significant changes in the differences for both men and women for the years 2010 and 2017 were occured.

\section{REFERENCES}

1. Boswell, Ch., \& Straubhaar, T. (2004). The illegal employment of foreign workers: An overview, Intereconomics. Heidelberg, 39(1), 4-7. Retrieved from https://www. econstor.eu/bitstream/10419/4182 3/1/37855980X.pdf

2. Cassel, D., \& Caspers, A. (1984) Was ist Schattenwirtschaft? Begriff und Erscheinungsformen der Sekond Economy. Wirtschaftswissenschaftliches Studium, 1, 1-7.

3. Davenport, Th. O. (1999). Human Capital What It Is and Why People Invest It (186 p.). San Francisco: Jossey-Bass Publishers.

4. Ehrenberg, R. G., \& Smith, R. S. (1997). Modern Labor Economics. New York: HarperCollins.

5. European Commission (1998). Communication of the Commission on Undeclared Work (COM (98)219). Brussels.

6. Eurostat (2018). Unemployment rate by sex. Retrieved from https:// ec.europa.eu/eurostat/tgm/table. $\mathrm{do} ? \mathrm{tab}=$ table\&init $=1$ \&plugin $=1 \& \mathrm{l}$ anguage $=$ en $\&$ p code $=$ tesem 120

7. Fierman, J. (1994, January 24) The Contingency Work Force. Fortune, 30-36.

8. Griffin, R. W. (2013). Fundamentals of management (216 p.). Texas
University. Retrieved from http:// www.pourlasolidarite.eu/sites/ default/files/publications/files/ report_illegal_work_of_migrants_ in_the_eu_0.pdf

9. Hussmanns, R. (2004). Measuring the informal economy: from employment in the informal sector to informal employment (Working Paper No. 53) (15 p.). International Labour Office, December.

10. Jędrzejowska-Schiffauer, I., \& Schiffauer, P. (2017). New constraints on mobility in Europe: Policy response to European crises or constitutional ambiguity? Journal of International Studies, 10(3), 9-23. https://doi.org/10.14254/20718330.2017/10-3/1

11. Jütting, J., \& Laiglesia, J. R. De (2009). Is Informal Normal? Towards More and Better Jobs in Developing Countries. OECD Development Centre, Paris.

12. Kucera, D., \& Xenogiani, T. (2009). Woman in Informal Employment: What Do We Know and What Can We Do? In J. Jütting \& J. R. De Laiglesia (Eds.), Is Informal Normal? Towards More and Better Jobs in Developing Countries (pp. 89-115). OECD Development Centre, Paris.
13. Lado, A., \& Wilson, M. (1994). Human Resource Systems and Sustained Competitive Advantage: A competency - Based Perspective. Academy of Management Review, 19(4), 699-727. https://doi. org/10.2307/258742

14. Medina, L., \& Schneider, F. (2018). Shadow Economies Around the World: What Did We Learn Over the Last 20 Years? (WP/18/17). International Monetary Fund, January.

15. Mikalauskiene, A., Streimikiene, D., \& Mazutaityte-Cepanoniene, E. (2017). Employers' Openness to Labour Immigrants. Econom$i c s$ and Sociology, 10(3), 25-45. https://doi.org/10.14254/2071789X.2017/10-3/2

16. Mróz, B. (2002). Gospodarka nieoficjalna $w$ systemie ekonomicznym (14 p.). Warszawa: Szkoła Główna Handlowa.

17. Penrose, E. T. (1997). The Theory of the Growth of the Firm. In N. J. Foss (Ed.), Resources, Firm and Strategies. A Reader in the Resource-Based Perspective (pp. 30-35). Oxford: Oxford University Press.

18. POUR LA SOLIDARITÉ (2014). The Illegal Work of Migrants In The European Union (Report of the Eu- 
ropean Community Programme for Employment and Social Solidarity PROGRESS). Retrieved from http://www.pourlasolidarite. eu/sites/default/files/publications/ files/report_illegal_work_of_migrants_in_the_eu_0.pdf

19. Schneider, F. (2007). Shadow Economies and Corruption All Over the World: New Estimates for 145 Countries. Jahannes Kepler University of Linz, Austria.

20. Simionescu, M., Ciuiu, D., Bilan, Y., \& Strielkowski, W. (2016). GDP and net migration in some eastern and south-eastern countries of Europe. A panel data and Bayesian approach. Montenegrin Journal of Economics, 12(2), 161-175. Retrieved from https://econpapers. repec.org/article/mjemjejnl/v_3a1 2_3ay_3a2016_3ai_3a2_3ap_ 3a161-175.htm

21. Terpstra, D., \& Rozell, E. (1993). The Relationship of Staffing Practices to Organizational Level Measures of Performance. Personnel Psychology, 27-38.
22. Torgler, B., \& Schneider, F. (2007). Shadow Economy, Tax Morale, Governance and Institutional Quality: A panel Analysis (IZA Discussion Paper Series, 9-10).

23. Tudose, M. B., \& Clipa, R. I. (2016). An analysis of the shadow economy in the EU countries. CES Working Papers, VIII(2), 303-312.

24. Wright, P., \& McMahan, G. (1992). Strategic Human Resources Management: A Review of the Literature. Journal of Management, 280-319. 